\title{
INFLUENCE OF INLET / SHOAL COMPLEX ON ADJACENT SHORELINES VIA INLET SINK METHOD
}

\author{
Kelly R. Legault, Ph.D., P.E. ${ }^{1}$, Tanya M. Beck ${ }^{2}$ and Jason A. Engle, P.E. ${ }^{3}$
}

\begin{abstract}
The region of influence of the inlet on the adjacent shoreline was determined via examination of the inlet's net sink effect. The net sink effect, or volumetric impact, was computed by adding the volume (or rate) of net sand accumulation within the inlet's channels and shoals with the cumulative volumetric losses on adjacent shorelines to conserve sediment mass after accounting for the volumes either added to adjacent beaches or removed from the ebb shoal by means of nourishment and sediment mining. Volume change of the beaches and ebb shoal complex was computed within a geospatial framework consisting of Regional Mapping and Analysis Program (RMAP), ArcGIS and the Surface-water Modeling System (SMS). Inlet-adjacent cumulative volume changes were then examined to discern the minimum distance away from the inlet along which this volumetric impact was manifest. The alongshore influence of the inlet as determined by the inlet sink method for the 1999-2010 time period was found to be 7.4 miles to the north and 5.5 miles to the south. The inlet sink effect for St. Augustine Inlet is $278,000 \mathrm{cu}$ yd/year, balanced by $99,000 \mathrm{cu} y d / y r$ of erosion from the north beaches and 179,000 cu yd/yr of erosion from the south beaches. If managed properly, the inlet could serve as a valuable, long-term resource for the beaches of St. Johns County within the bounds of its sink effect.
\end{abstract}

Keywords: inlet processes; sediment budget; inlet shoaling; beach volume change

\section{INTRODUCTION}

St. Johns County encompasses a $24-\mathrm{km}$ beach and inlet system located in northeast Florida on the Atlantic coastline of the United States (Fig. 1). Historical management practices at St. Augustine Inlet and the adjacent beaches have involved maintaining the navigation channel and placing dredged material onto adjacent beaches in moderate quantities ( 200-500K cu yd) since the 1970's (Dredging Information System (DIS) Database, maintained at USACE-SAJ). In 1998, an Inlet Management Plan (IMP) was developed (Taylor Engineering Inc. 1996) to guide sediment management practices at the Inlet. In the 2000s, severe erosion at a recurring hotspot south of St. Augustine Inlet at St. Augustine Beach, prompted local authorities to conduct larger scale beach nourishment projects to protect the shoreline.

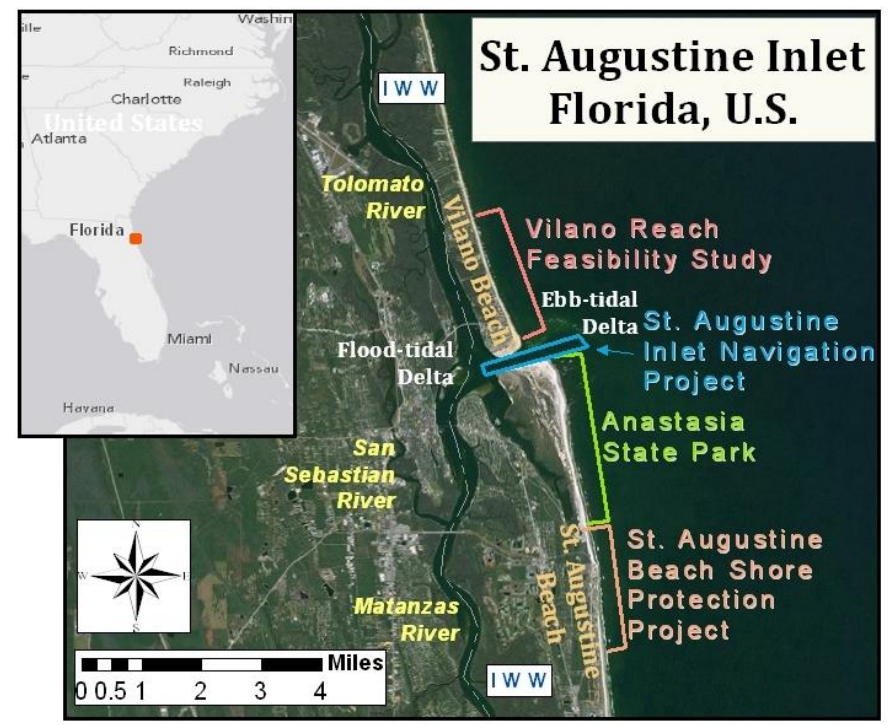

Figure 1. Study area location map for St. Johns County, Florida, and the U.S. Army Corps of Engineers' projects.: Vilano Reach Feasibility Study, St. Augustine Beach Nourishment Project, Intracoastal Waterway (IWW), and St. Augustine Inlet Navigation Project. The Vilano Shoal is located at the southern terminus of the Vilano Reach Feasibility Study, and the ebb shoal mining is located adjacent and offshore of the Inlet Navigation Project.

\footnotetext{
${ }^{1}$ Senior Coastal Engineer. U.S. Army Corps of Engineers, Jacksonville District, 701 San Marco Blvd. Jacksonville, FL 32205, USA

${ }^{2}$ Research Physical Scientist. U.S. Army Corps of Engineers, Coastal and Hydraulics Laboratory, Engineer Research and Development Center. 3909 Halls Ferry Rd. Vicksburg, MS 39180, USA

${ }^{3}$ Senior Coastal Engineer and Section Chief. U.S. Army Corps of Engineers, Jacksonville District, 701 San Marco Blvd. Jacksonville, FL 32205, USA.
} 
Between 2001 and 2005, the St. Augustine Beach Shore Protection Project (SPP) placed a total of 7 Mill cu yd (million cubic yards) of sediment that was mined from the outer lobe of the ebb shoal of St. Augustine Inlet.

A new IMP is under development to include the St. Augustine Beach SPP. Fundamental to its development was the quantification of beach and inlet volume change to answer salient questions concerning the historical and future impact of the management practices including the St. Augustine Beach SPP. Of particular interest were analyses to estimate the alongshore region of influence of the inlet and the inlet's net sink effect.

A comprehensive analysis of available bathymetric and topographic data was performed by the U.S. Army Engineer District, Jacksonville (hereafter, the Jacksonville District), and the Coastal Inlets Research Program (CIRP) at the Coastal and Hydraulics Laboratory (CHL), and are documented in Legault et al. (2012). These data were formulated into a present-day sediment budget in order to clearly define regional sediment dynamics for the purpose of subsequent regional sediment modeling and longterm planning of the sediment resources and shore protection needs for the county.

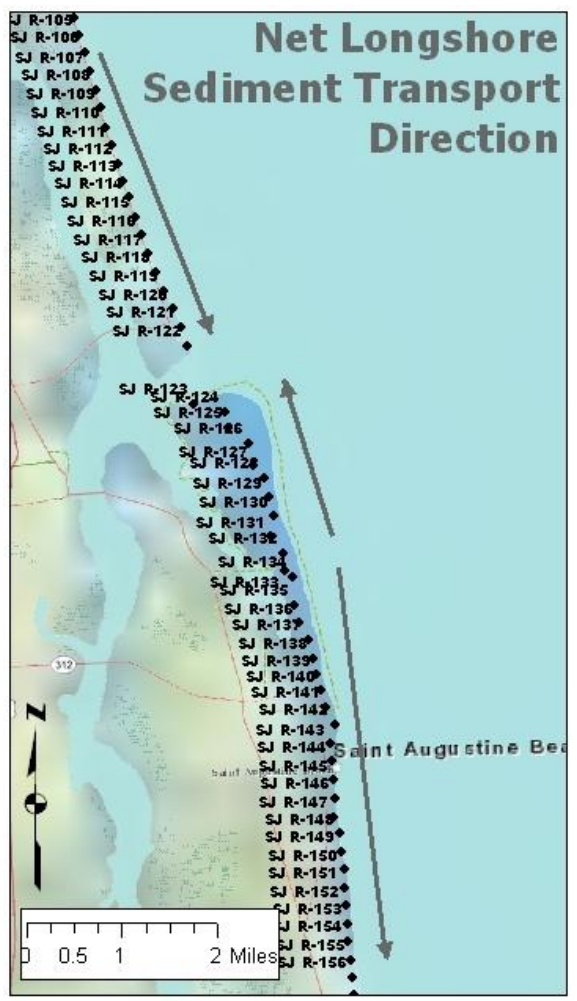

Figure 2. General net longshore sediment transport directions in the vicinity of the inlet.

\begin{tabular}{|c|c|}
\hline Date & Volume (mill cu yd) \\
\hline 1986 & 30.4 \\
\hline 1998 & 35.5 \\
\hline 1999 & 35.9 \\
\hline 2007 & 29.5 \\
\hline 2010 & 30.9 \\
\hline
\end{tabular}

\section{Study Area}

Sediments within the nearshore along northern St. Johns County are predominantly quartz sand with varying fractions of carbonate shell hash. The net direction of regional sand transport (Fig. 2) and general trends in volumetric change are described extensively by Legault et al. (2012).

Major dredging and beach fill operations at St. Augustine Beach were conducted in the early to mid-2000s using the navigation channel and the ebb shoal as a sediment source. Approximately 4.2 Mill cu and 2.8 Mill $\mathrm{cu}$ yd of sand was placed from 2001 to 2005 along the Federally-maintained Shore Protection Project at St. Augustine Beach (Legault et al. 2012). Table 1 lists ebb shoal volumes and Table 2 lists the volume of sediment removed from the inlet channel and its ebb shoal from 1986 to 2010. Nearly 7 Mill cu yd of sediment were removed from the inlet system between 1999 and 2007, and a slow recovery of sediment is reflected in the volumetric change of the ebb shoal in Table 1.

\begin{tabular}{|c|c|c|c|c|}
\hline Date & $\begin{array}{c}\text { Volume } \\
\text { Dredged } \\
\text { cu yd }\end{array}$ & $\begin{array}{c}\text { Nearshore } \\
\text { Placement } \\
\text { cu yd }\end{array}$ & $\begin{array}{c}\text { Beach Fill } \\
\text { cu yd }\end{array}$ & $\begin{array}{l}\text { Placement } \\
\text { Length (mi) }\end{array}$ \\
\hline 1986 & 121,247 & 121,247 & - & 2.6 \\
\hline 1996 & 257,649 & - & 257,649 & 2.6 \\
\hline 1997 & 130,000 & - & 130,000 & 2.6 \\
\hline 1998 & 130,000 & - & 130,000 & 2.6 \\
\hline 2001 & $2,200,000$ & - & $2,200,000$ & 1.1 \\
\hline 2002-03 & $2,000,000$ & - & $2,000,000$ & 3.6 \\
\hline 2005 & $2,800,000$ & - & $2,800,000$ & 2.6 \\
\hline
\end{tabular}




\section{SITE CHARACTERISTICS}

Fig. 3 shows representative profiles north and south of St. Augustine Inlet, at R-109 and R-150, respectively. North of the inlet typical dune crest elevations are $+20 \mathrm{ft}$ or greater, berm crest elevations are +4 to $+6 \mathrm{ft}$, and bar depths are between -8 and $-10 \mathrm{ft}$, all elevations relative to North American Vertical Datum 1988 (NAVD88). Typical dune crests south of the inlet are +18 to $+20 \mathrm{ft}$ with recent development of foredunes at +7 to $+10 \mathrm{ft}$ NAVD88; berm crests are similar to that north of the inlet. Bar depths south of the inlet range from -7 to $-14 \mathrm{ft}$ NAVD88. Beach slopes north and south of the inlet are approximately 1:55 and 1:80, respectively.

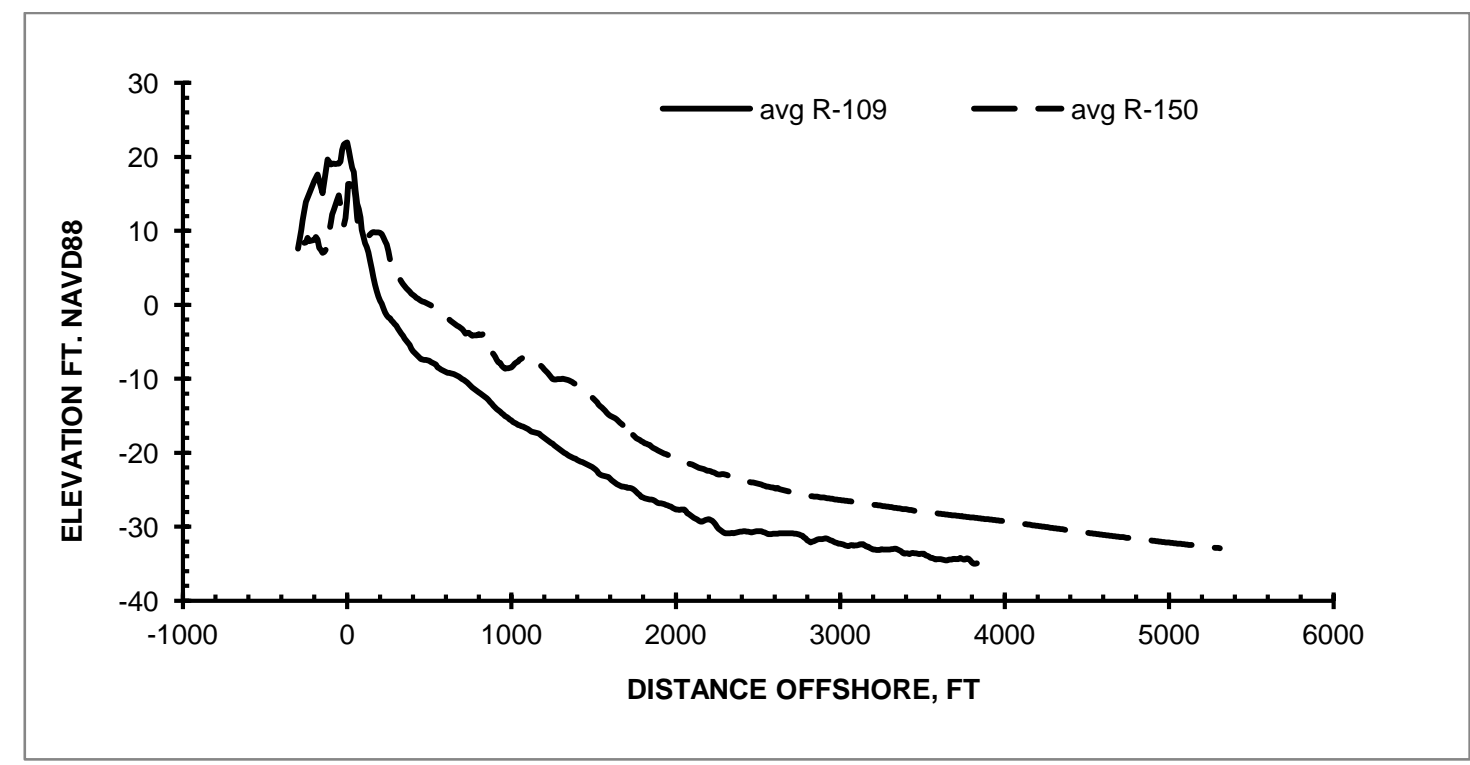

Figure 3. Representative cross-shore beach profiles (average profile; $1972-2010)$ north (R-109) and south (R-150) of St. Augustine Inlet.

In 2010, the ebb shoal at St. Augustine Inlet contained approximately 30.9 Mill cu yd (Fig. 4). After both shore protection projects between 2001 and 2005, the northern lobe of the ebb shoal was encroaching on the borrow site, but the most southeastern portion of the ebb shoal had not yet fully recovered as of 2010. The portion of the inlet channel which had been straightened by the navigation projects curved to the southeast depicting a more traditional alignment for this inlet.

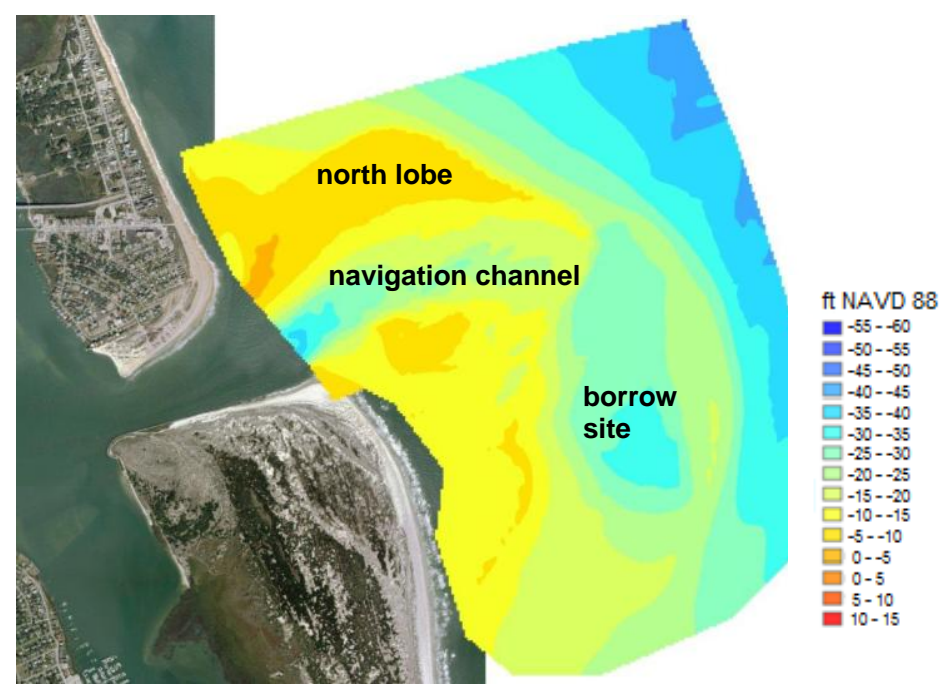

Figure 4. Ebb shoal bathymetry, Vilano and Anastasia Islands, October 2010. 


\section{METHODS}

Beach profile surveys were analyzed for volume change for the time period from $1999-2010$. The surveyed transects were imported into the Regional Morphology Analysis Program (RMAP) which was used to analyze volume change at each R-monument (range monument) profile location at approximately $1,000-\mathrm{ft}$ spacing.

Volumes within each profile were calculated by integrating under the profile offshore to a depth of closure that has been used in previous studies for this region, $20 \mathrm{ft}$ NAVD88. It is likely that the actual depth of closure is slightly deeper than this value. Closure depth, $h_{c}$, can be calculated for quartz-sand beaches from Hallermeier (1981) as,

$$
h_{c}=2.28 H_{e}-68.5\left(H_{e}^{2} / g T_{e}^{2}\right)
$$

where $H_{e}$ is the nearshore storm-wave height that is exceeded only 12 hours per year in meters, $T_{e}$ is the associated wave period in seconds, and $g$ is the gravitational acceleration equal to 9.81 $\mathrm{m} / \mathrm{sec}^{2}$. $H_{e}$ was determined using the near CDIP Buoy 132 at Fernandina Beach. Wave heights exceeded by only 12 hours per year were determined for the three years (2006 to 2008) that the buoy was in service. Depth of closure was determined to be $25.2 \mathrm{ft}$ as shown in Table 3. Profile volume change

\begin{tabular}{|l|c|c|c|}
\hline \multicolumn{4}{|c|}{$\begin{array}{c}\text { Table 3. Depth of Closure (DoC) Calculation (Eq. 1). } \\
\text { Selected Depth of Closure }=\mathbf{2 5 . 2} \mathbf{~ f t} \\
\text { (2008 values for } \boldsymbol{H}_{\boldsymbol{e}} \text { and } \boldsymbol{T}_{\boldsymbol{e}} \text { ) }\end{array}$} \\
\hline Year & $\boldsymbol{H}_{\boldsymbol{e}, \boldsymbol{m}} \boldsymbol{m}$ & $\boldsymbol{T}_{\boldsymbol{e}, \boldsymbol{s e c}}$ & DoC, $\boldsymbol{f t}$ \\
\hline $\mathbf{2 0 0 8}$ & $\mathbf{3 . 8 3}$ & $\mathbf{9 . 9}$ & $\mathbf{2 5 . 2}$ \\
2007 & 3.0 & 7.0 & 18.2 \\
2006 & 2.4 & 7.0 & 15.3 \\
\hline
\end{tabular}
per foot of linear beach was calculated for sequential time periods.

Profile volumes were integrated alongshore to obtain total volumes between beach profiles. The average end-area formula for finding the approximate volume of a prismoid was used to determine the volume between each beach profile as:

$$
V=\left(\frac{A_{1}+A_{2}}{2}\right) \cdot l
$$

where $V=$ volume; $A_{l}=$ area of one base; $A_{2}=$ area of the other base; $l=$ the perpendicular distance between bases. Profile reach volumes were summed over approximately a 5000-ft alongshore distance (five R-Monuments) to examine average annual volume change per 5000 linear alongshore feet for the time period from 1986 to 1999, (prior to ebb shoal mining) and for 1999 to 2007 and 1999 to 2010 (post-mining) (Figure 5).

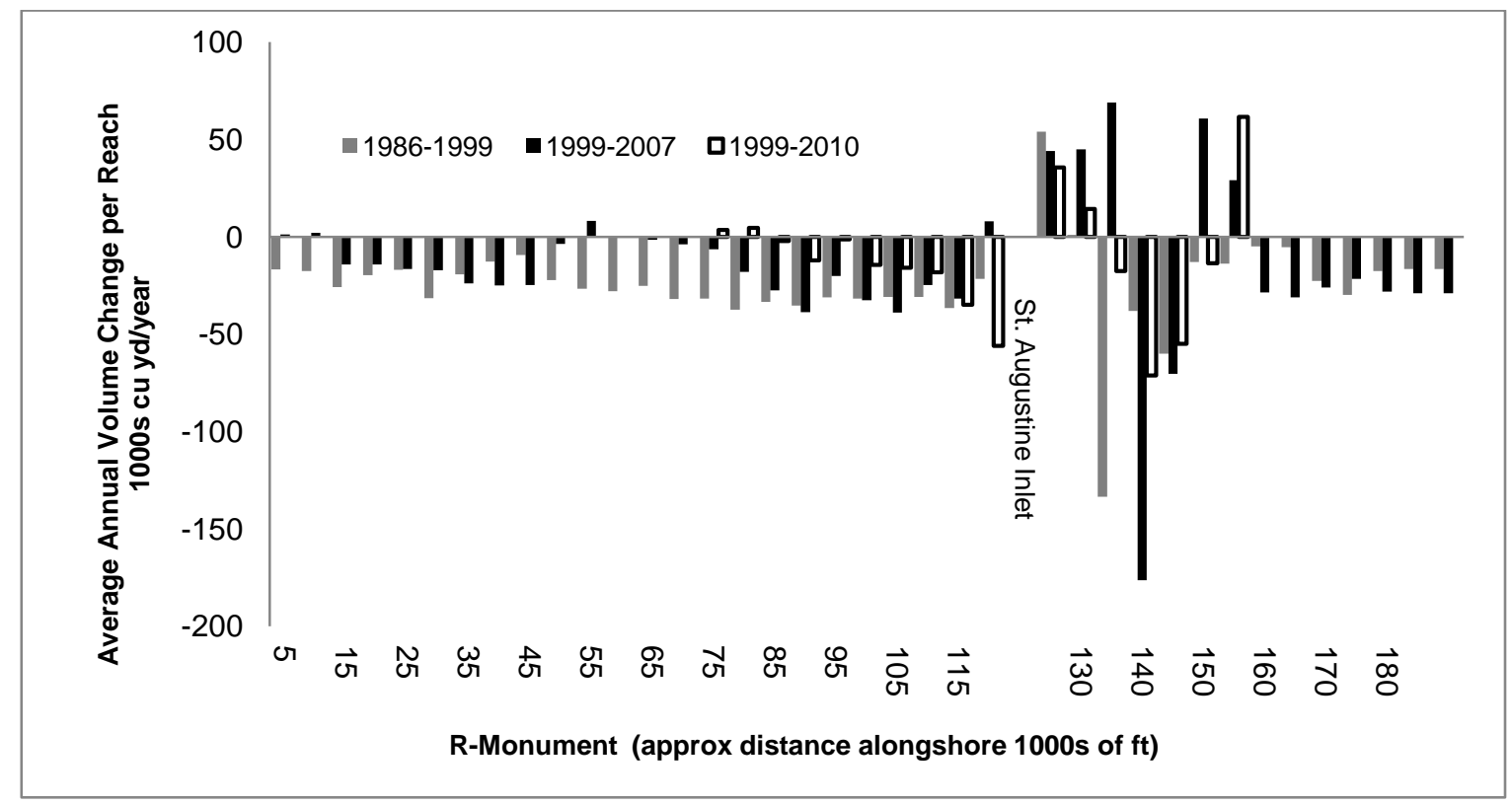

Figure 5. Average annual reach volume change 1986 to 1999, 1999 to 2007 (prior to ebb shoal mining), and 1999 to 2010 (post-mining). Reaches are approximately $5000 \mathrm{ft}$ in the alongshore. 
The rate of beach profile volume change north of the inlet was similar for all three time periods, except for the region at Guana River State Park, between R-46 and R-67 which showed a decrease in erosion for the 1999 to 2007 time period. The rate of erosion also decreased (and/or the rate of accretion increased) for the 1999 to 2010 period between R-73 and the inlet at R-122. South of the inlet, after having removed beach nourishment volumes, the beach at Anastasia State Park was accretional over all time periods from R-123 to R-125, and was both erosional and accretional through R-128. All time periods show accretion from R-129 to R-131 followed by consistent erosion to R-151. The St. Augustine Beach Pier located at R-142 is within the highly erosional area between R-138 and $\mathrm{R}-146$. There is one more generally accretive region from R-152 to R-159, followed by general erosion from R-160 southward to Matanzas Inlet.

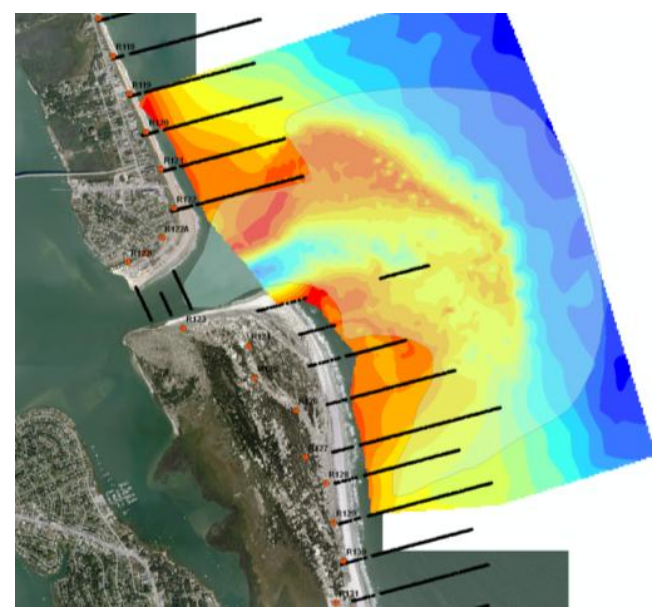

Figure 6. Surface raster of 1998 bathymetry of Ebb Shoal (NAVD 88); beach profile line survey points; ebb shoal mask (denoted by the transparent polygon over the bathymetry); elevations in $\mathrm{ft}$

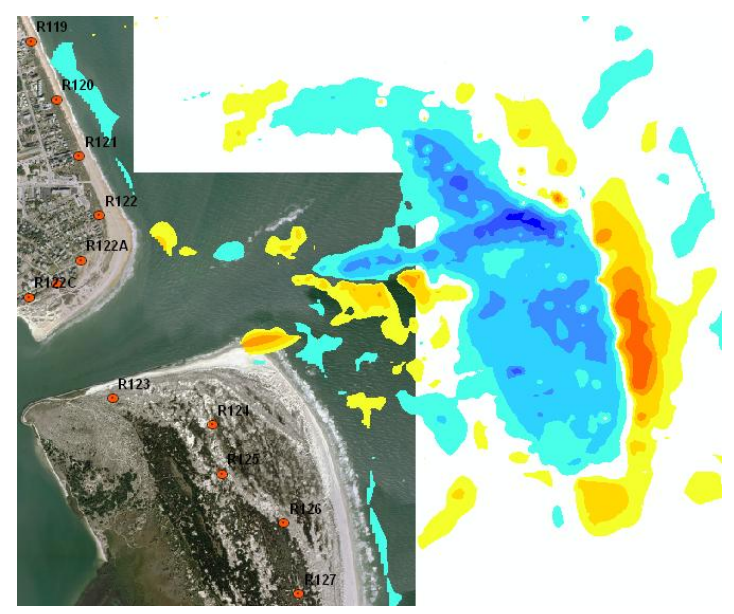

Figure 7. Difference in Ebb Shoal Elevation from 1998 to 2003 (post construction); Cool colors depict erosion or mining, warm colors depict accretion

Analysis of the ebb shoal volume change between surveys was made within a GIS framework using an area mask (Fig. 6) to ensure that the same regions were compared among all surveys. Attention was given to the elevations above depth of closure on the beach profiles directly adjacent to the inlet to ensure that they were not duplicated within the ebb shoal mask. GIS was used to analyze and compute area elevation changes and volumes gained or lost, as well as observe trends in morphologic patterns. Hydrographic survey points were interpolated to create a raster surface of the study area using natural neighbor interpolation. The area elevation changes were calculated by differencing rasters (Fig. 7) to determine the elevation change between surveys. Surface volume changes were computed within each survey mask for differenced rasters above and below a reference plane (in this case, NAVD88). Table 4 shows how the 1998 ebb shoal volume varied depending on which contour was defined as the offshore boundary of the polygon. Herein, the ebb shoal volume was calculated to $23 \mathrm{ft}$ and $30 \mathrm{ft}$, the approximate depth at which the ebb shoal has been mined in previous years. Table 5 details changes in ebb shoal volume and the rate of volume change.

In most cases, natural and stabilized inlets remove sand from the littoral system through accretion of adjacent shores, shoaling in channels, and accretion of ebb- and flood-tidal shoals. To assess the volumetric and lineal

\begin{tabular}{|l|c|c|}
\hline \multicolumn{3}{|c|}{ Table 5. Change in Ebb Shoal Volume } \\
\hline Interval & $\Delta$ V Ebb Shoal, cu yd & $\Delta$ V cu yd/yr \\
\hline $1986-1998$ & $5,071,250$ & 390,096 \\
$1998-2003$ & $1,065,849$ & 266,462 \\
$2003-2007$ & 866,938 & 216,735 \\
$1998-2007$ & $1,932,787$ & 241,598 \\
$1998-2009$ & $2,733,274$ & 248,480 \\
\hline
\end{tabular}

Table 4. 1998 Ebb shoal volume, cu yd.

$23 \mathrm{ft}$ Contour $26 \mathrm{ft}$ Contour $30 \mathrm{ft}$ Contour

$20,272,227 \quad 27,926,463 \quad 35,580,699$


extent of an inlet's effect upon the adjacent shorelines, a combination of analyses is typically necessary. In this case, we examined historical volumetric changes over the region of interest, and calculated the inlet's net sink effect. The inlet's sink effect first assesses the littoral impact within the inlet, and then identifies the adjacent shoreline length along which the inlet's volumetric impact is manifest.

Historic change in beach volume above -20ft NAVD was quantified for the time period between 1999 and 2010 to discern inlet's effect through examination of volume change. Local volume change (per unit alongshore beach width of 1,000 ft), was cumulatively summed along the shoreline, starting at the inlet $(\mathrm{x}=0)$ and continued to the updrift and downdrift beaches. The cumulative volume change as a function of distance from the inlet was plotted and examined to determine the location where a change in slope of the cumulative volume change appeared.

The inlet sink effect or the quantity of material that the inlet has captured from the littoral system was computed by adding: the volume change within the inlet's channels and shoals, the volume removed from the inlet's channels and shoals due to dredging, and the volume change in the flood shoal. The resulting value is the volume (or rate) of sand which has been removed from the adjacent shores' littoral systems over the period of examination. Inlet-adjacent volume changes are then examined to discern the minimum distance away from the inlet along which this volumetric impact is manifest using the historic change in beach volume as a guide.

\section{RESULTS}

Average annual cumulative volume change for the updrift (north) and downdrift (south) shorelines was calculated, starting at zero at the inlet and summing cumulatively at each R-monument both updrift and downdrift of the inlet. Downdrift volume change was calculated with and without the inclusion of beach nourishment volumes (Fig. 8). Nourishment volumes were removed from each profile reach based upon measured post-nourishment surveys (Taylor Engineering Inc. 2003, 2005). The alongshore reach of shoreline influenced by the inlet was determined through examination of the alongshore location where a change in slope (see arrows, Fig. 8) of the cumulative shoreline change or volume change exists when computed along the shoreline. The change in slope indicates that, up until this location, the beaches have significant connectivity (sediment exchange) and balance the volume that was captured by the inlet complex during the time of consideration. Cumulative beach profile change computed updrift and downdrift of the inlet (Fig. 8) was inspected to discern a change in slope of the plotted data (neglecting transects nearest the inlet) (see CEM EM 1110-2-1100 (V-6-30)).

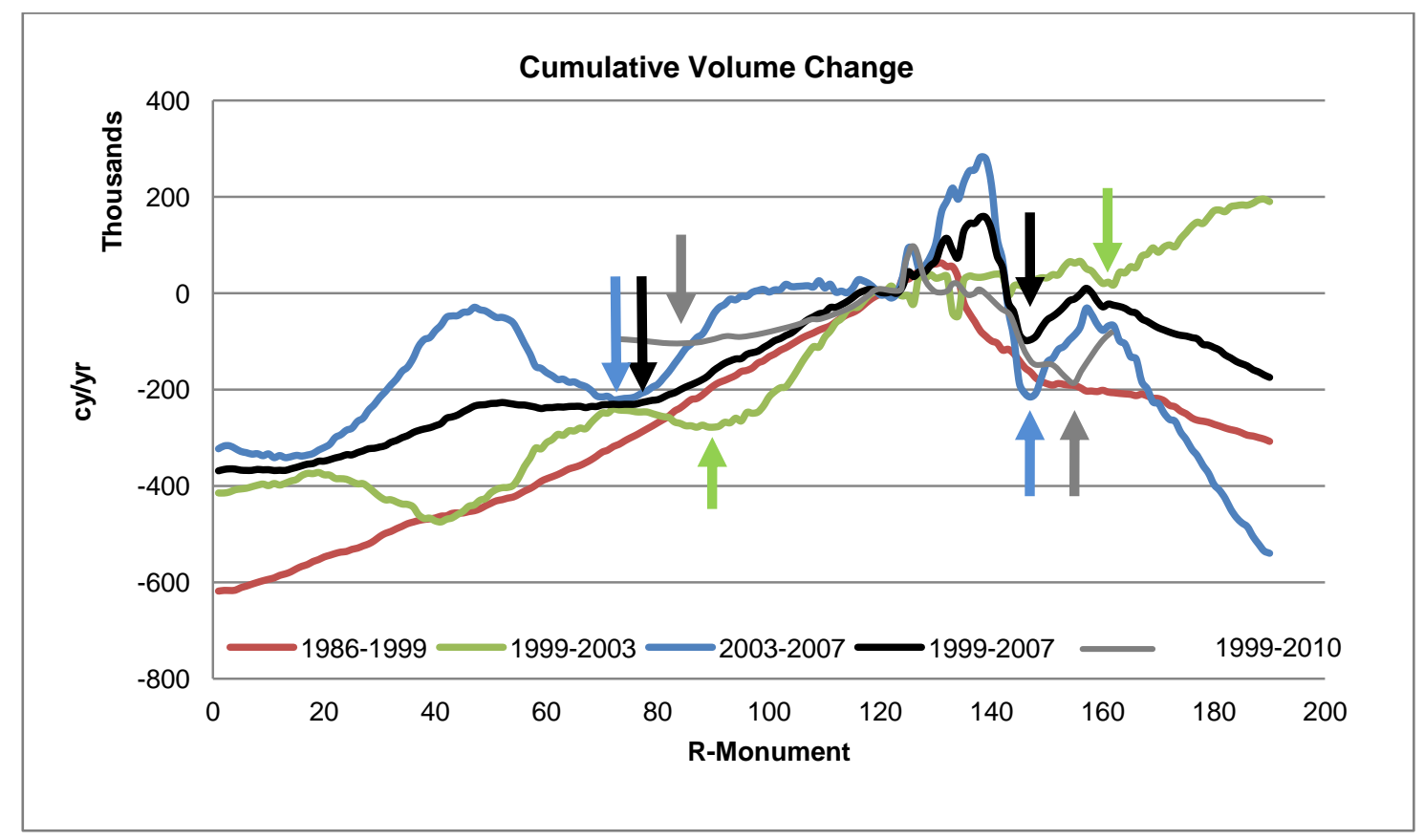

Figure 8. Cumulative beach profile volume change with and without beach nourishment, 1986-2010; arrows show the change in slope of the cumulative volume curves indicating the limit of inlet influence for each time period. 


\begin{tabular}{|c|c|c|r|}
\hline \multicolumn{2}{|c|}{ Table 6. Alongshore extent of inlet influence and associated cumulative volume change } \\
\hline \multirow{2}{*}{ Time Period } & \multicolumn{2}{|c|}{ R-monument and Volume, 1000s cu yd/yr } & \multicolumn{2}{c|}{$\begin{array}{c}\text { Total, 1000s } \\
\text { cu yd/yr }\end{array}$} \\
\cline { 2 - 4 } & North & South & $\mathrm{n} / \mathrm{a}$ \\
$1986-1999$ & Not discernible & Not discernible & -259.8 \\
$1999-2003$ & $\mathrm{R}-90,-277.7$ & $\mathrm{R}-160,+17.9$ & -436.6 \\
$2003-2007$ & $\mathrm{R}-72,-221.2$ & $\mathrm{R}-147,-215.4$ & -318.5 \\
$1999-2007$ & $\mathrm{R}-78,-220.9$ & $\mathrm{R}-146,-97.6$ & -278.1 \\
$1999-2010$ & $\mathrm{R}-83,-98.8$ & $\mathrm{R}-151,-179.3$ & \\
\hline
\end{tabular}

For the 1999 to 2003 period, change in slope for northerly and southerly beaches occurs at R-90 and R-160, respectively. For the 2003 to 2007 period, change in slope for northerly and southerly beaches occurs at R-72 and R-147, respectively. For 1999 to 2007, a southern change in slope can be observed at R-146; and a change at R-78 for the northern beaches. For 1986-1999, it was not possible to observe changes in slopes for the north or south beaches. For the 1999 to 2010 period, a maximum erosion of $-98,800 \mathrm{cu} \mathrm{yd/year}$ and a slight change in slope of the curve occur at R-83, north of the inlet. South of the inlet, the change in slope at R-151 is much easier to see, totaling $-179,300 \mathrm{cu}$ yd/year. Table 6 summarizes the analysis for each time period. These data can be applied to estimate the total rate at which the inlet has removed sand from the littoral system. For example, for the 1999 to 2010 data, the analysis implies that the total "sink" effect of the inlet should be approximately $-98,800+$ $-179,300 \mathrm{cu}$ yd/year, or, -278,100 cu yd/year.

\begin{tabular}{|c|c|c|c|c|c|}
\hline \multirow{2}{*}{ Time Period } & \multicolumn{2}{|c|}{$\begin{array}{l}\text { R-monument and Volume, 1000s } \\
\mathrm{cu} \mathrm{yd/yr}\end{array}$} & \multirow{2}{*}{$\begin{array}{l}\text { Ebb Shoal } \\
\text { Volume, } \\
1000 \mathrm{~s} \\
\text { cu yd/yr }\end{array}$} & \multirow{2}{*}{$\begin{array}{l}\text { Total, } \\
1000 \mathrm{~s} \\
\mathrm{cu} y \mathrm{~d} / \mathrm{yr}\end{array}$} & \multirow{2}{*}{$\begin{array}{l}\text { Residual, } \\
1000 \mathrm{~s} \\
\mathrm{cu} \mathrm{yd} / \mathrm{yr}\end{array}$} \\
\hline & North & South & & & \\
\hline 1986-1999 & $R-82,-261.5$ & R-144, -125.4 & 390.1 & -386.9 & 3.2 \\
\hline $1999-2003$ & R-90, -277.7 & $\mathrm{R}-160,+17.9$ & 266.5 & -259.8 & 6.7 \\
\hline 2003-2007 & R-72, -221.2 & $R-147,-215.4$ & 216.7 & -436.6 & -219.9 \\
\hline $1999-2007$ & R-78, -220.9 & R-146, -97.6 & 241.6 & -318.5 & -76.9 \\
\hline $1999-2010$ & R-83, -98.8 & $R-151,-179.3$ & 248.5 & -278.1 & -29.6 \\
\hline
\end{tabular}

Using results presented in Fig. 8 as guidance, we examined the inlet's sink effect for the 1999 to 2010 period in the alongshore region spanning R-72 to R-160. Integrated volumes were calculated for the reaches listed in Table 6 for updrift and downdrift beaches, respectively, for each time period. The change in beach volume was compared with the volume change in the inlet's ebb shoal complex over the same time duration (Table 7). Volume losses at the updrift and downdrift beaches compared well with volume gains at the ebb shoal (Fig. 9; Table 7) and residuals (losses updrift + losses downdrift + gains ebb shoal complex = residual) were <50,000 cy/yr over the 1986 to 1999,1999 to 2007, and 1999 to 2010 time periods. Good agreement indicates that the inlet effect is indeed realized in the region from approximately R-80 to the north to R-151 to the south. At different time periods, the specific location of the north and south boundary changes slightly, but in general, and over the long-term, R-80 and R-151 appear to be the bounds of the inlet effect. 


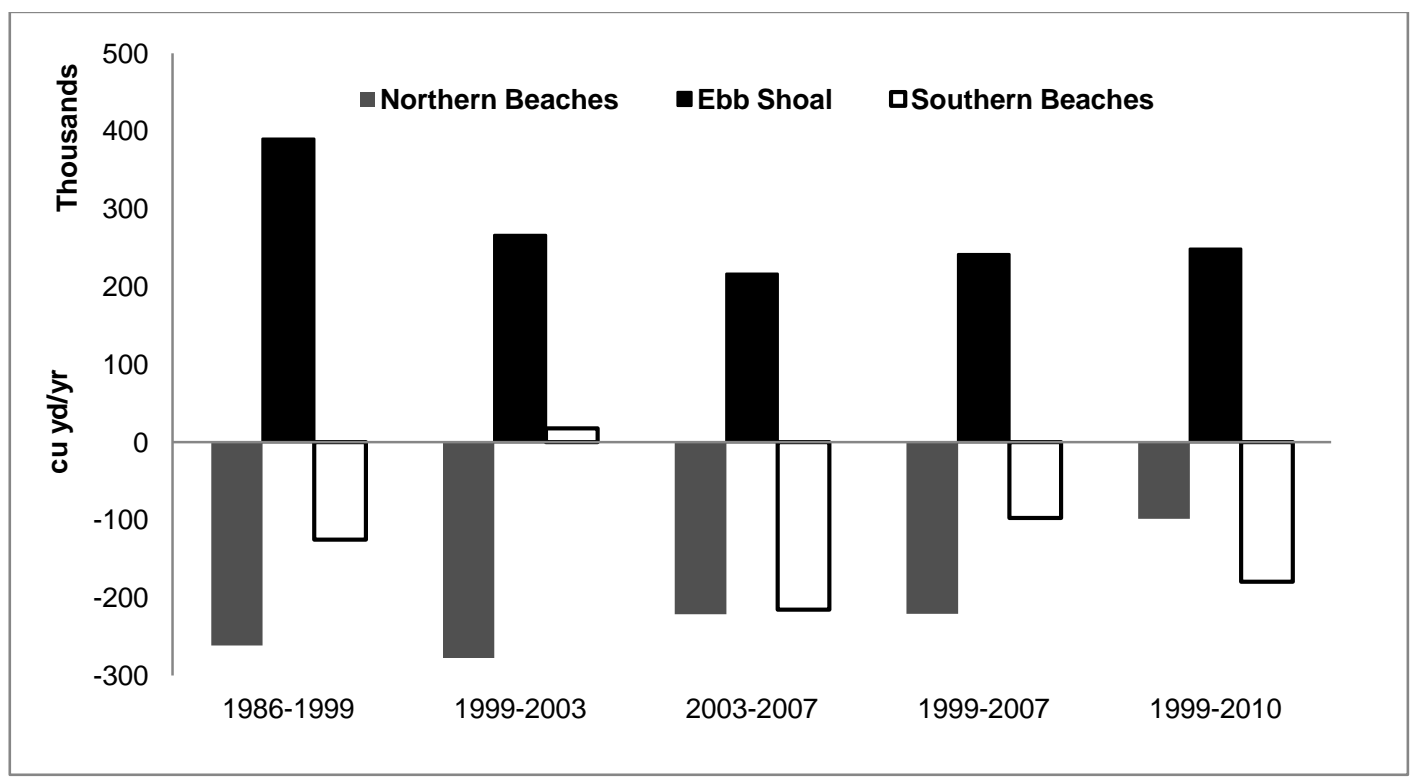

Figure 9. Volume Change north beaches, ebb shoal, and south beaches.

\section{DISCUSSION}

For 1999 to 2010, two alternatives were applied to evaluate the inlet sink, with two options each to represent volumetric change for the Flood Tidal Shoals + Channels (FTS\&C) (see e.g. Legault et al. 2012). Fig. 10 illustrates the regions used in each of the alternatives, Fig. 11 shows the numbering of these regions, and Table 8 summarizes the calculated sink for each alternative. For the FTS\&C, values were tested with the infilling rate as documented by Taylor Engineering, Inc. (1996) (110,500 cu $\mathrm{yd} /$ year) and a value of zero, then evaluated against the infilling rate that would balance the erosion of the adjacent beaches with accretion at the ebb shoal. The difference between Alternatives A and B is based upon the definition of the submerged platform fronting Anastasia State Park (Morphologic Zones 6 and 7 in Fig. 11) which can either be considered part of:

1. a continuous beach system fronting the adjacent beach (Anastasia State Park), or

2. the nearshore platform of the ebb shoal (inlet sink).

Table 8. Inlet sink analysis for 1999 to 2010.

\begin{tabular}{|c|c|c|c|c|c|c|c|}
\hline $\begin{array}{l}\text { Option and } \\
\text { Morphologic } \\
\text { Zones }\end{array}$ & $\begin{array}{l}\text { Volumetric } \\
\text { Rate } \\
\text { (cu yd/yr) }\end{array}$ & $\begin{array}{l}\text { Borrow } \\
\text { (cu yd/yr) }\end{array}$ & $\begin{array}{l}\text { Flood Tidal } \\
\text { Shoals and } \\
\text { Channels } \\
\text { (cu yd/yr) }\end{array}$ & $\begin{array}{l}\text { Inlet Sink } \\
\text { (cu yd/yr) }\end{array}$ & \multicolumn{2}{|c|}{$\begin{array}{l}\text { Adjacent Beaches } \\
\text { (cu yd/yr) }\end{array}$} & $\begin{array}{l}\text { Imbalance } \\
\text { (cu yd/yr) }\end{array}$ \\
\hline A: $1-7,9$ & $-385,236$ & & & $\begin{array}{l}\text { A1) } 360,046 \\
\text { A2) } 249,546 \\
\text { A3) } 278,091\end{array}$ & & $-179,266$ & $\begin{array}{l}\text { A1) } 81,955 \\
\text { A2) }-28,545 \\
\text { A3) } 0\end{array}$ \\
\hline B: $2-5,9$ & $-147,142$ & 634,783 & $\begin{array}{l}\text { 1) } 110,500 \\
\text { 2) } 0 \\
\text { 3) } 28,545\end{array}$ & $\begin{array}{l}\text { B1) } 598,140 \\
\text { B2) } 487,640 \\
\text { B3) } 516,185\end{array}$ & $\begin{array}{c}\text { Add } \\
\text { Morph } \\
\text { Zone 1: } \\
-138,870\end{array}$ & $\begin{array}{c}\text { Add } \\
\text { Morph } \\
\text { Zones } \\
6+7: \\
-377,315\end{array}$ & $\begin{array}{l}\text { B1) } 81,955 \\
\text { B2) }-28,545 \\
\text { B3) } 0\end{array}$ \\
\hline $\begin{array}{l}\text { A3) Selected } \\
\text { Option for the } \\
\text { Inlet Sink }\end{array}$ & $-385,236$ & 634,783 & 28,545 & 278,091 & $-98,824$ & $-179,266$ & 0 \\
\hline
\end{tabular}

From a geomorphologic standpoint, cells 1 through 7 (Fig. 11) collectively are a part of the ebb shoal proper. Typically the morphology of the ebb shoal inlet complex is studied using either aerial photographs, satellite imagery, or measured topography and bathymetry. With the aid of these tools, the identification and the location of the inlet and shoal components, such as the main channel, flood 
marginal channels, outer shield and nearshore platform, becomes rather straightforward . However, from the point of view from the beach itself, it is difficult to discern exactly which features that represent the submerged beach and those that represent the ebb shoal. For the sink analysis, if a portion of the volume change was not assigned to the "inlet sink," it was assigned by R-monument to the "adjacent beaches." Each alternative for the inlet sink was independently evaluated against the associated adjacent beach cumulative change. Table 8 summarizes the associated adjacent beach cumulative rate of change for each Alternative.
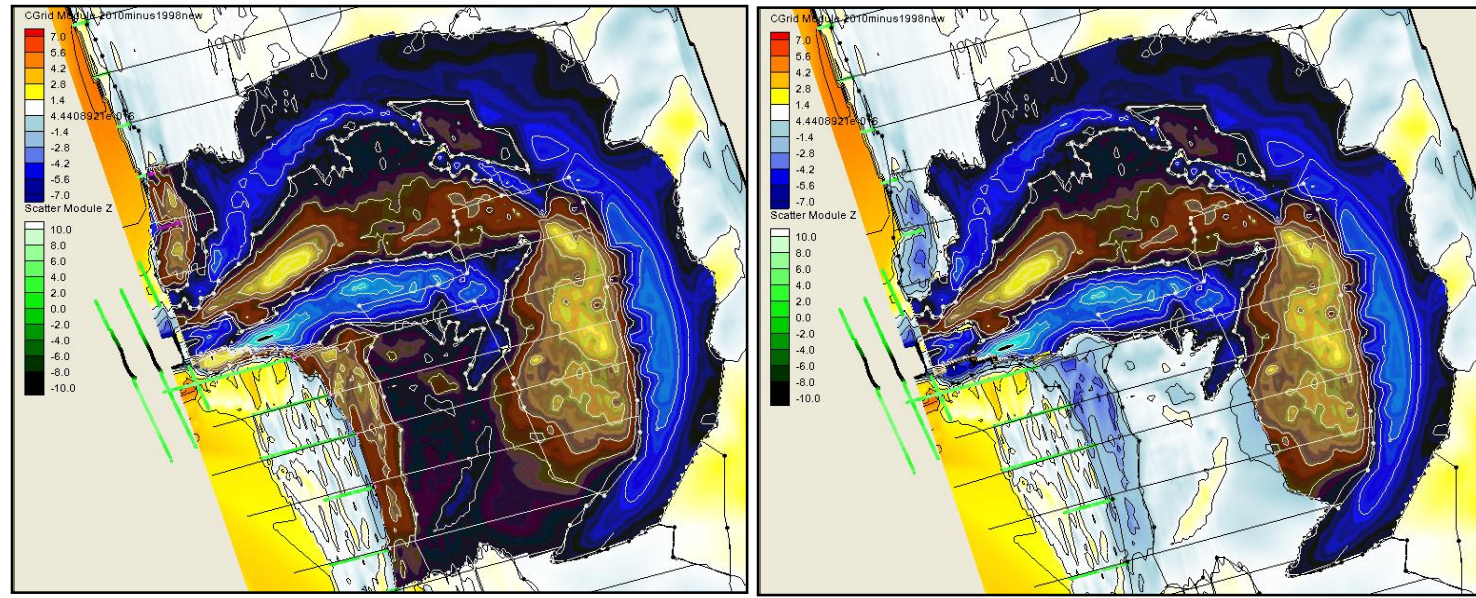

Figure 10. Regions of St. Augustine Inlet used to evaluate the 1999 to 2010 inlet sink: a. (LEFT) all 9 morphologic zones; b. (RIGHT) morphologic zones 2-5, 9.

The "Imbalance" column in Table 8 shows the degree to which the rate of Inlet Sink is realized on the adjacent beaches. To balance the cumulative adjacent beach change, the flood tidal shoals and interior channels would need to accrete at a rate of $28,545 \mathrm{cu}$ yd/year or erode at a rate of $81,955 \mathrm{cu}$ yd/year (Table 8 , right column). Because flood tidal shoals are typically sinks for sand (accretive), and in the absence of measurements for the FTS\&C for the 1999 to 2010 period, a volumetric change rate for the FTS\&C equal to $+28,545 \mathrm{cu}$ yd/year was adopted. Given the ranges of net and gross transport rates in the area, Option A3 was selected as the most likely option that describes the function of the inlet sink. Thus the total inlet sink for use in the sediment budget formulation was 278,091 cu yd/year, which is balanced by alongshore erosion equal to $-98,824 \mathrm{cu} \mathrm{yd/year}$ north of St. Augustine Inlet and $-179,266 \mathrm{cu}$ yd/year south of the inlet.

It is important to note that results from the inlet sink method are affected by the allocation of morphologic zones to define either the

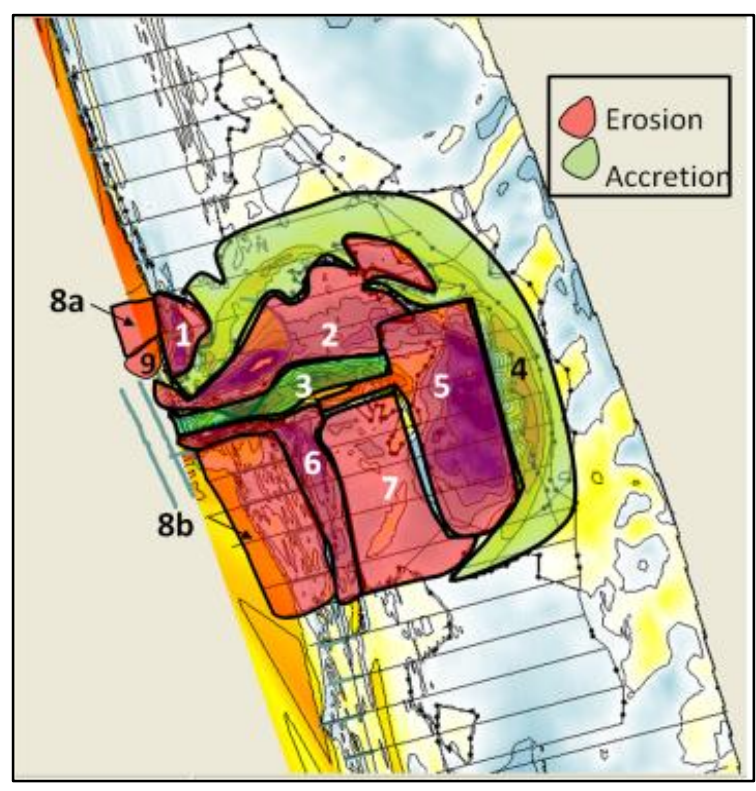

Figure 11. Numbering of Morphologic Zones within St. Augustine Inlet used to evaluate the 1999 to 2010 inlet sink. "adjacent beaches" or to the "inlet sink". For example, considering that the offshore submerged platform fronting Anastasia State Park is a part of the beach system (Morphologic Zones 6 and 7 in Fig. 11), the resulting sediment budget indicates $516,185 \mathrm{cu} y d / y r$ of accretion in the ebb shoal (Morphologic Zones 2-5 and 9, Table 8) and 377,315 cu $\mathrm{yd} / \mathrm{yr}$ of erosion on the adjacent beaches to the south. 
The total inlet sink for the 1974 to 1995 period was approximated as the sum of the inlet ebb shoal, inlet-subaerial beaches, and interior inlet-channel rates of volume change, or 508,200 cu yd/year. The total inlet sink for the 1999 to 2010 period is 278,091 cu yd/year, or approximately 55\% of the earlier value. There could be many reasons for this difference. The foremost reason for this difference is the continued evolution of the ebb shoal. In 1974, the ebb shoal was clearly evolving with offshore contours that were relatively straight and parallel (Legault et. al 2012). In 1995, the ebb shoal is further developed, is compact and has a better defined outer (bar) shield than in 1974. By 2010, the outer shield extended further offshore as the ebb shoal continued its development (Legault et. al 2012). Second, as discussed previously, the very definition of the extent of ebb shoal itself, as evidenced by Options A and B in Table 8 can change the relative adjacent beach volume accretion rate. The 1999 to 2010 inlet sink effect was altered by the allocation of morphologic zones to define either the "adjacent beaches" or to the "inlet and ebb shoal complex".

\section{CONCLUSIONS}

The alongshore influence of the inlet as determined by the inlet sink method for the 1999-2010 time period was found to be 7.4 miles to the north and 5.5 miles to the south. Profile data analyzed from 1999 to 2003, 2003 to 2007, and the combined period 1999 to 2007 indicate distances north equal to 6.1, 9.1 and 8.0 miles, respectively, reinforcing the longer impact distance north of the inlet. For the same periods of time, southern impact distances were 7.0, 4.5, and 4.5 miles, respectively. The inlet sink effect for St. Augustine Inlet is $278,000 \mathrm{cu} \mathrm{yd} / \mathrm{yr}$ which is balanced by approximately $99,000 \mathrm{cu}$ $\mathrm{yd} / \mathrm{yr}$ of erosion from the beaches to the north and $179,000 \mathrm{cu} \mathrm{yd} / \mathrm{yr}$ of erosion from the beaches to the south. If managed properly, the Inlet could serve as a valuable resource for the beaches of St. Johns County within the bounds of its sink effect, ensuring that the sediment withdrawn from the ebb shoal is not greater than the inlet sink value calculated from the bathymetry and topography measured between 1999 and 2010 .

\section{ACKNOWLEDGMENTS}

This project was partially funded by the National Regional Sediment Management and Coastal Inlets Research Programs of the U.S. Army Corps of Engineers. The authors would like to thank Dr. Julie Dean Rosati for invaluable suggestions which improved the quality of the work.

\section{REFERENCES}

Legault K.R., J.D. Rosati, J. Engle, and T.M. Beck. 2012. St. Johns County, St. Augustine Inlet, FL Report 1: Historical Analysis and Sediment Budget. Technical Report ERDC-TR-12-4: Report 1, U.S. Army Research and Development Center, Coastal and Hydraulics Laboratory, Vicksburg, MS.

Taylor Engineering, Inc. 1996. Inlet Baseline Conditions Physical and Environmental Characteristics. St. Augustine Inlet Management Plan - Part 2, St. Johns County, Florida.

Taylor Engineering, Inc. 2003. 2003 Monitoring Report. St. Johns County Shore Protection Project, St. Johns County, Florida.

Taylor Engineering, Inc. 2005. 2004 Monitoring Report. St. Johns County Shore Protection Project, St. Johns County, Florida.

USACE. 2008. Coastal Engineering Manual. EM 1110-2-1100 (Part V) 31 Jul 03. http://chl.erdc.usace.army.mil/cem.

USACE-SAJ. 2010. Dredging Information System (DIS) Database, maintained by the U.S. Army Corps Engineer Jacksonville District, Jacksonville, Florida. 